Society for Latin American Studies (SLAS)

Venezuela, April 2002: Coup or Popular Rebellion? The Myth of a United Venezuela Author(s): Barry Cannon

Source: Bulletin of Latin American Research, Vol. 23, No. 3 (Jul., 2004), pp. 285-302

Published by: Wiley on behalf of Society for Latin American Studies (SLAS)

Stable URL: https://www.jstor.org/stable/27733658

Accessed: 10-07-2019 11:29 UTC

JSTOR is a not-for-profit service that helps scholars, researchers, and students discover, use, and build upon a wide range of content in a trusted digital archive. We use information technology and tools to increase productivity and facilitate new forms of scholarship. For more information about JSTOR, please contact support@jstor.org.

Your use of the JSTOR archive indicates your acceptance of the Terms \& Conditions of Use, available at https://about.jstor.org/terms

Society for Latin American Studies (SLAS), Wiley are collaborating with JSTOR to digitize, preserve and extend access to Bulletin of Latin American Research 


\title{
Venezuela, April 2002: Coup or Popular Rebellion? The Myth of a United Venezuela
}

\author{
BARRY CANNON \\ School of Communications, Dublin City University, Dublin, Ireland
}

\begin{abstract}
This article assesses the merits of opposing National Assembly reports into the coup against President Chávez of Venezuela in April 2002. Looking at the historical context and the content of the reports, it argues that the two opposing accounts reflect a class division that has always existed in Venezuela but has been officially denied. It concludes that a possible exit from the stalemate could be that the opposition accept the reality of this class division and therefore the Chávez government as a legitimate representative of the popular classes. This, however, is unlikely in the present circumstances.
\end{abstract}

Keywords. Chávez, class polarisation, coup, National Assembly (reports into the coup), opposition, Venezuela.

\section{Introduction}

In April 2002, a series of events occurred in Venezuela, which to this day illustrate starkly the depth of division and polarisation in that country. During that month, the Workers Confederation of Venezuela [Confederación de Trabajadores de Venezuela (CTV)] and the business federation Fedecámaras led a series of demonstrations and work stoppages aimed at overthrowing the elected government of President Hugo Chávez Frías. These actions were supported by almost the entire print, electronic and radio media, opposition political parties, a number of civil organisations and nongovernmental organisations (NGOs), sectors of the Armed Forces and much of the middle classes and the more established working classes represented by the CTV. On Thursday 11 April, the opposition held a multitudinous march to the headquarters of the state oil company Petroleos de Venezuela SA (PDVSA) in the east of Caracas, which on arriving at that destination was directed by the leadership of the march, without warning or permission of the authorities, to the presidential palace in the centre of the capital. In the environs of the palace, up to twenty people were shot dead and many more were wounded, many of them amongst the marchers, but many also amongst pro-government demonstrators who had gathered around the palace to defend it. During the following 3 days, the government of Chávez Frías was toppled, a new 


\section{Barry Cannon}

government led by the leader of Fedecamaras, Pedro Carmona Estanga, was installed only to be itself deposed, with Chávez returning early on Sunday 14 April.

These events have since been interpreted by the government and its supporters as a "coup", while opposition sectors and supporters refer to them as a "popular insurrection". How is it that two such polarised visions of demonstrable events can emerge in one country? It could be argued that both accounts of the events of April 2002 reflect not so much different views of the same demonstrable facts, but rather different visions of Venezuela as a nation. Both accounts reflect two opposing analyses of a continuously evolving process of polarisation between an economically enfranchised minority and the economically disenfranchised majority. Underlying these analyses is an ongoing struggle about the extent and nature of marketled reforms between a heterogeneous Opposition, and a statist government as represented by Chávez.

The struggle in Venezuela, however, has not emerged out of a vacuum, nor is it simply about the supremacy of one economic model over another; rather it is the contemporary expression of the multiple economic, social, cultural and racial fractures which have defined Venezuelan society since colonial times. In contemporary Venezuelan society, these fractures have become centred on a class-based political polarisation of society between the popular classes, composed of some sections of the unorganised working class, the unemployed and informal sectors, and the organised working, middle and upper classes, composed of salaried working and professional sectors and capitalist groups. This has led to a 'renewed political salience of social inequalities (...) bringing the axis of political competition into closer alignment with underlying structural cleavages' (Roberts, 2003:62-63). Chávez recognised and capitalised on this development, politically outstripping the other parties who were unable or unwilling to adapt to the new sociopolitical realities.

This article attempts to answer the question posed in the title by first looking at the history of the country and the historical background to the emergence of Chávez. I argue in this section that Venezuela has consistently been riven by multiple divisions, which have been papered over by successive regimes, perpetuating a myth of a united, classless Venezuela. It will then look at the run-up to the coup, and the government and opposition versions of the events of April 2002, as set out in the parallel reports produced by both sides in the Asamblea Nacional (National Assembly; AN), discussing the validity of each. Finally, in the conclusion, I argue that a key part of the opposition strategy is to deny the existence of class polarisation in Venezuelan society by attributing its existence solely to the discourse of the president. The ideas and strategies used by many in the opposition, nevertheless, are equally as ideological and polarising as those of the government. The article concludes that both sides need to accept the validity of the others' argument. Furthermore, I argue that the opposition in particular should construct policies which truly acknowledge the class divisions of Venezuela, thus recognising Chávez as a legitimate representative of the Venezuelan popular sectors and his government as the legitimate government of Venezuela. Nonetheless in the current polarised political climate in Venezuela, this is unlikely to happen. 
Venezuela, April 2002: Coup or Popular Rebellion?

\section{Historical Context}

Venezuelan society has been polarised around conceptions of civilisation and barbarism, knowledge and ignorance and rich and poor since its inception. The political response to this polarisation has been its denial through the imposition of authoritarian rule for most of its history, ${ }^{1}$ and from 1958 to 1998 by the imposition of a unique system of democratic rule described by Rey (1991) as a 'populist system of conciliation'. The essential struggle epitomised by the differing views of April 2002 is a continuation of the historically opposed visions of Venezuela dating back to colonial times, of creole (whites) on the one hand and pardo (mixed race) and slave (black) on the other, identified by Carrera Damas (1980). While the Creoles sought to liberate themselves from Spain to perpetuate and deepen the colonial occupation and exploitation of Venezuela, the pardos and slaves sought their own personal physical, social and economic liberation. Venezuela's independence was thus born under the sign of a double ideology, that of the liberal conception of the state, in Carrera Damas' words 'the ideological trap of the dominant class' (ibid 86-87) and of social liberation for the dominated sectors. Bolívar was the living embodiment of this dichotomy being at once a member of the dominant classes and Venezuela's greatest ideologue of liberal concepts of liberty and equality. Nonetheless, the liberal conception of the state was the triumphant ideology which emerged from the struggles which wreaked havoc in Venezuela during the first half of the nineteenth century, establishing its hegemony to the point where 'it was not possible to conceive of the State or society under any other form of organisation' (ibid 1980: 108).

Concepts of liberty and equality, however, became an essential part of the fabrication of legality through its codification in successive constitutions. The republic was thus formed under a dichotic conception, that of social justice and equality, which was more legal aspiration than social fact, and of Creole domination of the economic, social and political life of the country (ibid 1980: 96). In effect, the structural inequalities and colonial objectives inherited from the Spanish remained intact; that is, the use of free or cheap labour for the purposes of occupying and exploiting the territory for the financial and social gain of the elite. Thus a 'total disassociation between legal codes, government practice, class segregation and collective conscience developed [which] has persisted up until this day' (Carvallo, 1994:146).

For the most part, this hegemony was exercised politically through autocracy aimed at the continued implantation of the capitalist system and the perpetuation of the elites as the dominant classes and natural rulers of Venezuela. Initially, this autocracy was effected through internal class struggles led by caudillos, or military strongmen, for domination of the fledgling Venezuelan State. However, autocracy was later perfected in the dictatorship of Antonio Guzman Blanco (1870-1888), in what Carrera Damas refers to as a 'civilising' autocracy, that is an autocracy which further developed the 'tyranny' of the ruling classes through an intense programme of modernisation (Carvallo, 1999:109).

1 'The country had experienced only 8 months of civilian-elected government during its first century and a quarter of independence (1830-1958)' (Myers, 1996:229). 


\section{Barry Cannon}

Coronil and Skurski (1991) identify the concept of history in Venezuelan national discourse as one of 'the uncertain advance of civilisation over barbarism'. Guzman Blanco and Juan Vincente Goméz (1908-1935) were the political expressions of this concept, self-styled heirs of Bolívar as they embodied like him 'the union between civilising force and barbarous energy that must be reproduced in the struggle to achieve historical progress' (Coronil and Skurski, 1991:297). These rulers, 'democratic Caesars' to paraphrase Vallenilla Lanz (1999), became 'civilisers' of the barbaric masses through modernising policies that built the foundations of the Venezuelan state, its bureaucracies, transportation networks, and most importantly under Goméz its oil industry, while always formally observing the official liberal ideology of the Venezuelan elite. This bourgeois elite, with its access particularly to the United States and Europe, was the font of received wisdom, importing ideologies and implanting 'modernisation' on the 'barbarous' body of the Venezuelan nation. Meanwhile a 'racial dualism' developed, where on the one hand a process of miscegenation was taking place, and on the other hand blacks, and to a lesser extent pardos, were subject to social and economic exploitation (Wright, 1990:14). As modernisation processes developed, concepts of civilisation, race and social and economic domination became intertwined with class divisions.

\section{The Triumph and Consolidation of Liberal Democracy 1945-1989}

The transformation of Venezuela into an oil state during the Goméz regime brought with it a decline of agriculture and an increasing migration to the cities, which in turn stimulated the growth of an urban bourgeoisie who developed new conceptions of the liberal state, more in tune with the times and demands of a rapidly modernising oil state. The 'generation of $28^{, 2}$ developed a liberal democratic approach to governing that revolved around the twin principles of political liberty and economic entitlement, the former based on universal suffrage and the latter on the control of Venezuela's oil wealth and its exploitation on behalf of the 'totality of the Venezuelan people' (Suarez Figueroa quoted in Coronil, 1997:96).

The installation of liberal democracy, first in 1945 and again, definitively, in 1958, was in itself an illustration of the civil-military dichotomy of Venezuelan society. Most governments in Venezuela up until then had been led by military personnel or installed by the military. The installation of democratic regimes under Acción Democrática was no exception, as both were effected by means of a coup. Venezuelan democracy, therefore, was definitively installed through non-democratic means.

Rey (1991) described the Venezuelan democratic system as 'a populist system of conciliation' based on a number of explicit and implicit pacts. The foundation of the system was the Punto Fijo pact ${ }^{3}$ where each party promised to abide by the electoral

2 Name of a group of students and activists of the Central University of Venezuela (UCV) who rebelled against the Gomez dictatorship. Romulo Betancourt, Raul Leoni, Pio Tamayo and Jovita Villalba were among them.

3 Named after Rafael Caldera's (leader and founder member of Copei, the Christian Democratic party) house in Caracas where the pact was formulated and signed by Caldera, Betancourt (AD) and Villalba (URD) on 31 October 1958. 
rules and relinquish power when required by electoral outcomes of the popular vote. Significantly, the left was excluded from participating, despite the important role played by the Partido Comunista Venezolano [Communist Party of Venezuela (PCV)] in the struggle against the Peréz Jímenez dictatorship. Indeed, Betancourt actively pursued the exclusion of the left from Venezuelan politics by both peaceful and violent means (Ewell, 1984:131). Not until 1973 did the left begin to appear once again in Venezuelan parliamentary politics, and an 'undercurrent of political resentment (...) ran just below the surface of Venezuelan politics' throughout the Punto Fijo era due to AD's hegemonic exclusionary policies against the left, which would 'resurface with the crisis of legitimacy after 1989' (Hellinger, 2003:28-29).

The Punto Fijo regime was set up to reconcile the complex dichotomous tendencies in Venezuelan society and politics: between elite domination and popular demands for equality, the military and civilians, 'barbarism' and 'civilisation', the private and public economies, dominated and dominating classes, etc. It developed as a 'complex system of negotiation and accommodation of heterogeneous interests in which mechanisms of a utilitarian type played a central role in the generation of support for the regime and furthermore, its maintenance in power' (Rey, 1991:543). The system was a delicate balancing act between the interests of powerful minority sectors and maintaining the confidence of the majority in the system, as the best means to achieve 'liberty, justice and wellbeing' (Rey, 1991:543).

The Punto Fijo regime was designed to avoid conflict and antagonism, encourage conciliation and negate the polarisation of Venezuelan society along class lines (Carvallo and López Maya, 1989:48). Initially, AD was oriented towards and supported by lower class constituencies and Copei to better-off communities. As time went by, however, this class cleavage eroded as the party system developed and became institutionalised, and the parties became 'archetypal multiclass, catchall electoral organisations' (Roberts, 2003:58-59). As the system consolidated, the economic model began to be exhausted under the weight of a slump in oil prices and increased external borrowing, and 'a false image of consensus was created', leading to a mistrust and subsequent exclusion of dissent (Civit and España, 1989:39). From Black Friday in February 1983, when the government of Luis Herrera Campins dramatically devalued the bolívar in the face of a slump in oil prices and massive capital flight, the Punto Fijo regime began to lose support (Lander, 1996:50).

'Puntofijismo' had a number of important achievements, principally political stability, confidence of the population in the democratic regime and its leadership and relative economic growth, not to mention improved educational, health and general living standards for the majority of Venezuelans (Kornblith, 1989:145). Nonetheless, the fundamental flaw in the Punto Fijo design was the contradiction between the liberal democratic order on the juridical constitutional level and the reformist character of the social and economic order (Carrera Damas, 1980:187). Once the pillar of a limitless oil income fell, and the addiction to indebtedness took hold, the contradiction between these two parts became manifest and the model became unsustainable. Both parts of the Punto Fijo equation became irreconcilable, and with it the fragile system of consensus became divided once again along class lines. Increasingly, the notion gained currency amongst some elite sectors that it was no longer possible to give to one sector 


\section{Barry Cannon}

without taking from the other. The question was which sector was going to pay. In the context of the increased global hegemony of the market, the Venezuelan economic elite began to press more urgently for reforms that made the popular classes pay. Meanwhile, the formal defenders of the popular classes, such as the CTV, actively collaborated or stood on the sidelines leaving the majority of the population without effective representation (Civit and España, 1989:39). It was no longer possible to conceal the multiple social fractures in the political order of Venezuela.

This became most apparent during the Caracazo (27-28 February 1989), a huge popular explosion of discontent against radical market-oriented reforms introduced by President Carlos Andrés Peréz (1989-1993). Residents of Caracas' teeming shantytowns, and those of other major cities, came down from the cerros (hills) and proceeded to loot shops and warehouses, initially for food, but as the disturbances developed, for all sorts of consumer goods. Government reaction was initially tame but eventually President Pérez called a state of emergency and left it to the Army and police to quell the disturbances. The result was the use of 'massive violence', an official death toll of 277, and an unofficial one running into the thousands (Coronil and Skurski, 1991:326).

The establishment reading of the Caracazo was the eruption of barbarism, of primitivism pitted against civilisation (Coronil and Skurski, 1991:327). The pueblo (people) was a source of barbarism, the government and the elite a force for reason and civilisation: ' $[t]$ he nation was split in two' (Coronil and Skurski, 1991:328). The Caracazo symbolised the eruption of the class factor once again into national politics (Carvallo and López Maya, 1989:48). ${ }^{4}$ Even the president acknowledged this in a speech to the nation on 28 February, a notion violently rejected by Fedecámaras (Carvallo and López Maya, 1989:50-51). The CTV, due to its position both within the power structure and as representatives of working people, also avoided acknowledging the inescapable class nature of the Caracazo and the measures which sparked it off (Carvallo and López Maya, 1989:51). Despite the President's recognition of the class nature of the disturbances and his reforms, he persisted in implementing them, leading initially to some macroeconomic success but by 1992 unemployment, informalisation of employment and poverty had all increased (Lander, 1996). In 1989 alone, poverty increased from 46 to 62 per cent of the population, while those living in extreme poverty more than doubled, from 14 to 30 per cent of the population (Roberts, 2003:59).

The Comisión Presidencial para la Reforma del Estado (Presidential Commission for the Reform of the State; COPRE) ${ }^{5}$ led to the emergence or consolidation of movements representing the popular sectors, such as the Movimiento al Socialismo (Movement to Socialism, MAS), La Causa Radical (Radical Cause; LCR) and Chávez's Movimiento Bolivariano Revolucionario-200 (Bolivarian Revolutionary Movement-200; MBR-200)

4 After the Caracazo, Venezuela would not be the same again as protest became the norm, increasing in incidence, violence and variety and extending to almost all sectors of society (López Maya, 2002).

5 Process begun in 1984 attempting to reform the state and make it more responsive democratically. One of its most far-reaching measures was decentralisation at state and municipal level, allowing new parties and movements to have power bases. 
amongst others. ${ }^{6}$ These movements began to organise around alternative trades unions organisations (LCR) or in the army (MBR-200), and some began to achieve representation in governorships and in Congress. LCR and MAS, however, accepted the system's rules whilst seeking to reform them, while the MBR-200 sought to replace the system entirely. Meanwhile, the multi-class systemic parties $\mathrm{AD}$ and Copei faced a precipitous decline in the face of this heightened class conflict. They found themselves unable either to comprehensively represent the increasingly divergent interests of the different classes, or to definitively transform themselves into class-based parties representing one or other side of the social divide. Rafael Caldera, sensing this, abandoned the party he founded, Copei, and won the elections in 1993 through an alliance with MAS, other smaller parties and his own electoral vehicle Convergencía (Common Direction). Yet, such reforms could not re-establish people's faith in Venezuelan democratic institutions. In 1982, for example, almost 60 per cent of the population had a positive image of political parties, but by 1992 around 60 per cent had a negative image (Njaim, Combellas and Alvarez, 1998:17) Furthermore, almost 40 per cent of those surveyed had a negative opinion on the constitutional system as it existed, especially marked amongst lower class sectors (Njaim, Combellas and Alvarez, 1998:99-100). Causes for the crisis were blamed on corruption, the parties, the economic situation and the lack of participation in the political process (Njaim, Combellas and Alvarez, 1998:106). The system had lost its legitimacy with the electorate and the Punto Fijo attempt at modernisation finally resulted in mass alienation rather than the mass loyalty so nearly gained through the policy of 'sowing the oil'.

Puntofijismo ultimately had done little to tackle income inequalities, and as the crisis set in so popular class income levels worsened. As Roberts (2003:60) points out 'during a period of generalised macroeconomic decline, income became more highly concentrated, and society became more sharply divided between elite and popular sectors'. Venezuelans saw their standard of living plummet: between 1990 and 1997 per capita income fell from $\$ 5192$ to $\$ 2858$ and the country's human development index fell from 0.8210 to 0.7046 (OCEI/PNUD, 2001:92). The Venezuelan middle and upper classes shrunk beyond recognition from over 40 per cent of the population in 1989 to around 10 per cent by 1999 (Hellinger, 2003:38). Open unemployment grew from 6.6 per cent in 1980 to 15.4 per cent in 1999 , much of that decline in the agricultural and industrial sectors in favour of the service sector (Roberts, 2003:60). Informalisation of employment grew from 34.5 per cent in 1980 to 53 per cent in 1999 (Roberts, 2003:60). In 1978, 10 per cent of the population lived in general poverty and just 2 per cent in extreme poverty, but by 1990 these figures had risen to 40 and 14.6 per cent, respectively and by 1999, 49.4 and 21.7 per cent (Buxton 2003:115; ECLAC, 2002:212).

In such a devastating economic scenario, as the popular classes became the majority, so estrangement from the system became more marked amongst those groups. Disapproval of the constitutional system was highest amongst the informal groups and the unemployed and approval highest amongst businessmen and industrialists (Njaim,

6 See Ellner (1986) on MAS; Lopéz Maya (1996) on La Causa R and MBR-200. 


\section{Barry Cannon}

Combellas and Alverez, 1998:99-100). By 1998, most voters identified themselves as independents and eschewed party identification (Datanalisis, 1998:28). Voting patterns showed increasing abstentionism from a low of 3.5 per cent in 1973 to a high of 39.8 per cent in 1993, a tendency which has remained ever since (McCoy and Smith, 1995:137). ${ }^{7}$ Venezuelan society became increasingly polarised along social and economic lines, leading to a stronger class-consciousness amongst popular and middle sectors, which was reflected in estrangement from the system.

The government of President Rafael Caldera (1993-1998) tried to implement piecemeal neoliberal reform under the Agenda Venezuela programme, but Venezuela's crisis continued to deepen and widen, and in the increased breach between the political establishment and all sectors of society a search for political alternatives and new political and economic models was under way. In 1997, the MBR-200 became a new electoral movement, the Movimiento Quinta Republica (Fifth Republic Movement, MVR) and began to prepare for the 1998 elections. ${ }^{8}$ The MVR quickly became an electoral grouping for the original military core of the movement, the once-excluded vanguardist left, and many members of the established parties disenchanted with their policies. It forged alliances with a number of parties on the left, such as Patria Para Todos (Motherland for Everyone, PPT) a more radical excision of LCR; MAS, which had been in alliance with Caldera's Convergencia movement; and smaller parties such as the PCV amongst others, to create the Polo Patriótico (Patriotic Pole; PP). Chávez won the presidential elections with $56 \%$ of the votes, the PP winning $33 \%$ of the seats in both houses of Congress (Lingenthal, 1999:222-223). While the Chávez vote had strong penetration at all levels, polls suggested that his appeal was particularly strong amongst the popular classes, whereas his chief rival Henrique Salas Römer's appeal was amongst the middle and upper sectors (Roberts, 2003:66). A similar social class division was repeated in the 2000 elections: 50.5 per cent of socioeconomic sector E voted for Chávez as opposed to 24 per cent for Arias Cazdenas, ex Coup companion of Chávez, while 66.7 per cent of socioeconomic groups $\mathrm{A} / \mathrm{B}$ voted for the latter (El Universal, 6 April 2000). Despite a consistent opposition campaign against the President, the concentration of supporters amongst the lowest social levels, according to polls, remains strong. In July 2001, the President retained strongest support amongst social sector E, while rejection was strongest amongst A, B and C groups (Datanalisis, 2001:21). More recently, despite a fall of support amongst the popular sectors, an opposition poll still showed strongest support for the President amongst sectors D (31 per cent) and E (35 per cent) as opposed to only 16 and 27 per cent support for the President amongst social sectors $\mathrm{ABC}+$ and C, respectively (Primero Justicia, 2003:8). One poll suggests that in a fresh election 33.6 per cent would vote in favour of Chávez staying in power, and in an open presidential election with various candidates, 29.4 per

7 Polls before the 1998 and 2000 elections showed that the poorest parts of the population were the least likely to vote (Hellinger, 2003:44).

8 It was illegal to use the name of the Liberator, Bolívar, for political parties in Venezuela. By using V, the roman numeral for five, the movement's name remained unchanged verbally due to the similarity in Spanish pronunciation of the $b$ and $v$ consonants. 
cent would vote for the President (El Universal, 20 June 2003). Coppedge (2002:4-5) therefore is correct when he points out that: 'The size of Chávez's base of electoral support [..] remains solid in comparative perspective [with previous Venezuelan presidents and other Latin American leaders]'. Furthermore, Chávez's rise 'signified a repoliticisation of social inequality in Venezuela' with mostly the popular sectors identifying with Chávez and the middle and upper sectors with opponents of the president (Roberts, 2003:55).

Chávez and the MVR therefore recognise and capitalise on the fundamental class polarisation of Venezuelan society, as Chávez's repeated references to the Venezuelan elites as 'oligarchs' signify. Furthermore, it is Chávez's very rejection of neoliberalism which provides much of his popular appeal. Salas Römer promised a short sharp shock therapy, which was rejected by the electorate (Buxton, 2003:124). As Ellner (2003:16) points out 'the presidential elections of 1988, 1993, 1998 and 2000 represented popular mandates to avoid the neoliberal approach, which both Presidents Peréz and Caldera ignored'. Furthermore, rejection of this approach, poll data would suggest, is strongest amongst the popular classes. This signifies that any candidate who promotes the implantation of a market-dominated economic model is practically assured [electoral] defeat' (Datanalisis, 1998:16).

\section{April 2002: Coup or Popular Rebellion?}

\section{Context}

Despite this politicisation of social inequality and the concentration of support of the middle and upper classes in favour of opposition candidates, ideological homogeneity amongst the opposition to the President is not apparent. The parties supporting Salas in 1998 , for example, were to the right of the ideological spectrum, while those supporting Arias in 2000 were to the left. ${ }^{9}$ Nevertheless, both candidates received support from the upper socioeconomic brackets. Furthermore, few of Chávez's policies while in office seriously prejudiced middle- and upper-class privilege, nor to date have they seriously affected poverty. This suggests that opposition to Chávez, and support for him, is based not just on ideological or material actions, but also on other more profound psychological, moral and class-based fears and prejudices.

Objectively speaking, the opposition had a number of grounds to seriously question the legitimacy of the Chávez government. First, the Constitution of 1999 strengthened the power of the Executive by extending the presidential term from 5 to 6 years, providing the possibility of re-election for one more period, and strengthening the power of the president over the Armed Forces. There was increased centralisation with less autonomy for regional and municipal powers, PDVSA and the Central Bank. Furthermore, as the president's term advanced, he developed signs of authoritarianism

9 Salas was supported by his own ProVenezuela movement, AD and Copei amongst others. Arias was supported by, for example, LCR and Bandera Roja, a far left party which once supported the armed struggle. 


\section{Barry Cannon}

and disrespect for the adversary. There was evidence of some disregard for the Constitution in the appointment of judges to the Supreme Court (TSJ) and to the National Electoral Council as well as the appointment of the State Prosecutor and the Ombudsman (PROVEA, 2002:17). Appointment to public office was based on their political attachments of the incumbents rather than popular participation in their selection as required by the Constitution (ibid:27). There were threats to freedom of expression in the media, including violent threats from supposedly armed, governmentcreated Bolivarian Circles (ibid:18), a lack of inclusion of concerned groups in policy formulation as stipulated in the Constitution and inconsistencies between electoral promises and government action (ibid:20-21). The President's belligerent, exclusive discourse and increased militarisation of the government were also points of concern (ibid:23).

Second, the government's claim to electoral legitimacy was particularly weakened in such a context, considering the high levels of abstentionism in elections and referenda. Almost 50 per cent abstained in the elections of 1998; 62 per cent in the referendum for the Constituent Assembly (April 1999); 54 per cent in Constituent Assembly elections (July 1999); 56 per cent in the referendum approving the new Constitution (December, 1999) (Buxton, 2000:29); 43 per cent in the 2000 Presidential elections (Fleischer, 2000); 76.50 per cent in Trade Union leadership referendum, December 2000 (Consejo Nacional Electoral (CNE), 2003). Buxton (2000) can therefore point out with accuracy that the Chávez government's radical institutional reform was carried out without the expressed support of a majority of Venezuelans.

Finally, Parker (2002) lists a number of factors which caused the opposition to harden its positions and bring with it middle- and upper-class support. The government's attempt to make the CTV more representative of the broader categories of workers through the referendum of December 2000, the election of Carlos Ortega to the presidency of that organisation, and the continuing difficulties between government and CTV, brought that organism firmly into the opposition camp. A hurriedly introduced set of 49 Enabling Laws, affecting interests such as landowners, and the oil industry, long a middle- and upper-class preserve, led Fedecámaras, already unfavourably disposed to the government, to take an even more robust stance against it. Perceived attacks on the Church's preserve of private education, continued attempts to take more control of the oil industry, the so-called 'drip' of military personnel in open rebellion against the government, and consistent attacks on the media led to the eventual eclipsing of the political parties in the opposition leadership and their replacement by these social sectors, with Fedecámaras, the CTV and the media in the lead.

In sum, government actions increased an already high level of rejection amongst the bulk of the middle and upper classes. Various fronts of indiscriminate conflict ensued, which 'without doubt helped to unify the opposition, not around an alternative project, but rather behind the slogan "out with Chávez"' (González Plessmann, 2002:14). As Chávez consolidated his power and conflict intensified with pro-system actors in contradiction to Venezuela's traditional consensus politics, the hegemonic struggle became discursively centred on 'democracy' and not class. Chávez narrowed his focus to encompass all those who sought consensual reformist politics, whatever their ideological background. In so doing, the differing opposition fragments found a 
centralising ideological discursive element which could successfully obscure the fundamental class divisions of Venezuelan society as reflected in their own divisiveness and uncertain ideological consensus.

\section{Government and Opposition Accounts of the Coup}

The prelude to the April 2002 coup was a series of highly publicised work stoppages and marches, which once again showed polarisation along class lines. Most opposition marches were held in the wealthier sectors in the east of Caracas, while marches in support of the President were held in the poorer western sectors, and during opposition stoppages informal workers continued to work (Hellinger, 2003:49). The coup itself took place during an opposition march, which began in the wealthier east of the city, and it was the poor from the peripheral barrios who returned Chávez to power.

Shortly after the April events of 2002, Venezuela's National Assembly instigated a parliamentary investigation into the events, which eventually produced two irreconcilable accounts further reflecting the political aspect of this polarisation. On the one hand, the opposition account described the events as a 'constitutional rebellion' against the government of President Chávez, but on the other hand, the government and its supporters clearly labelled it a golpe de estado. It proved impossible to reach a compromise, resulting in the publication of two separate reports reflecting the polarised nature of Venezuelan society and politics.

The accounts differed on most of the fundamental events of the coup. The opposition report maintained that only Chávez was to blame for the situation, as he had created a context of ungovernability due to his repeated infringements of the Constitution. This had prompted a huge march on 11 April which was peaceful, unarmed, and hence was not insurrectional, as the government maintained, as it did 'not have the characteristics to define it as such' (Tablante, 2002). Nonetheless, the President had permitted and/or ordered the Bolivarian Circles, Armed Forces and the National Guard to open fire on the demonstrators, and hence he was the only person responsible for their deaths. This left the Armed Forces no choice but to defend the Venezuelan people by seeking the president's resignation in support of the civic insurrection. According to Army Chief Vazquez Velasco, it was not a coup, nor insubordination 'but a position of solidarity with all the Venezuelan people'.

The government account (Asamblea Nacional, 2002), however, stated that it was the opposition who deliberately created this situation of ungovernability and chaos as part of a plan to facilitate the coup, and as such was responsible for the deaths which occurred on 11 April. The march became insurrectional when it changed its route to the Presidential Palace of Miraflores with the express purpose of violently removing the President from office. The events could only be termed a coup as they were planned conspiratorially with sectors of the military, business, opposition and media involved. Its execution had military hallmarks, including the leading of the march to the Palace, road blocks set up on some of the main highways and finally snipers, from the Metropolitan and other opposition police forces, stationed at key points near the 


\section{Barry Cannon}

Palace. These snipers opened fire on government supporters, causing the latter to defend themselves, and on opposition demonstrators too.

According to the opposition account, as chaos reigned outside the Palace and its environs, the Armed Forces 'rebelled' under Article 350 of the Constitution, ${ }^{10}$ and as Chávez appeared to have resigned, a 'constitutional power vacuum' was therefore created. The Armed Forces turned to Pedro Carmona Estanga to fulfil the presidential role in the interim. Once Carmona became the President, however, he proceeded to break with the constitutional order by abolishing all the Constitutional powers and appointing a new government in a ten-point decree read out in Miraflores (Carmona, 2002). With this act, Carmona alienated many of the principal political parties, the CTV, sectors of civil society and the Army and as a result eventually had to stand down, paving the way for the return of Chávez to the presidency.

The government account, however, strongly rejects the notion of a 'constitutional power vacuum'. Chávez could not have resigned because he was kidnapped and was being held incommunicado. In such circumstances, his resignation would have been by definition against his will, the National Assembly would have had to ratify it, and the Vice-President should have become President. None of this took place and hence, the government report argues, the 'power vacuum' was unconstitutional and the Carmona government de facto. Furthermore, the Carmona government had no basis in popular support, with no political programme to speak of and no real plan to assure power. The result was chaos and the deaths, arrest and torture of many civilians and government officers and supporters in the ensuing few days.

Which of these accounts is the most accurate? Rey (2002:14) agrees with the opposition insofar as recognising that the President's authoritarian tendencies and the resulting polarisation increased the former's desperation. Legal options to a change of government, in the short term, seemed unworkable, thus increasing the likelihood of a coup being used to effect its removal. He has no doubt, however, that the events constituted a coup and not a 'constitutional rebellion' as the opposition claim. First, he states that it was impossible for Chávez to resign 'voluntarily' in such a situation because there were clear pressures from the military for him to do so, and thus it could not have been of his own free will and as such was unconstitutional (Rey, 2002:6). Second, the theory of the 'constitutional power vacuum' is a fallacy behind which the perpetrators of the coup wished to obscure the army's role in the deposing of the President. It was clear that it was the Armed Forces and not Carmona who was in charge. There was rather, according to Rey, an 'unconstitutional power vacuum' because the President had been illegally imprisoned, and the Vice-President was in hiding to avoid the same fate, yet there was no military leader prepared to assume power (Rey, 2002:10). Those who signed the decree had no claim to representation of the people, the majority being unelected members of interest groups. Carmona claimed that he had a popular mandate, as a result of the march on 11 April, but the march was

10 Article 350: 'The Venezuelan People, faithful to their republican tradition, and the struggle for their independence, peace, liberty, will withdraw recognition from any regime, legislation, or authority which contradicts the valued, principles, and democratic guarantees or violates human rights' (Tablante, 2002:41). 


\section{Venezuela, April 2002: Coup or Popular Rebellion?}

against Chávez and not acclaiming him as the new President (Rey, 2002:12). The coup failed because there was no clear leadership or ideological proposal behind it (Rey, 2002:13). Yet, those who participated in the coup could not recognise it as such, first because of the negative connotations such an act has within Venezuela, second, because it would have been illegal and finally because any government owing its existence to a coup would have failed to win support under the Interamerican Democratic Charter (Rey, 2002:12-13). Rey's analysis would thus agree substantially with the government deputies' analysis outlined above.

Furthermore, there are clear inconsistencies in the opposition discourse and their own behaviour before, during and after the coup, which are omitted from the opposition account. Opposition criticisms of the government's aggressive behaviour towards them do not take account of the persistent, equally aggressive and almost universal media campaign against the government at both home and abroad (Various authors, 2002; Werz, 2001). Their complaints about Chávez's attacks on the media and the effects this had on freedom of expression were compromised by their almost total disregard for transmitting the facts during the coup. Indeed, according to one analyst, 'there was an information blackout planned in solidarity or connivance with the de facto government [of Carmona]' (González Plessmann, 2002: 20).

The complaints about the government arming groups of supporters do not take account of violent attacks on targets connected to the government, the possibility of opposition agents provacateurs causing violence or the use of smear tactics by the media. ${ }^{11}$ Furthermore, the general climate of violence and the gun culture found throughout Venezuela makes it highly likely that both sides will have armed groups within their ranks, especially in such a polarised situation.

One of the principal criticisms of Chávez by the opposition, as I have already signalled, is the lack of independent institutions and the rule of law. Yet, during the brief government of Carmona, all institutions were abolished leaving the country effectively without the rule of law. Many of those from 'civil society', who had previously criticised Chávez on this issue, were present at the ceremony where Carmona announced his decrees and published an advertisement in support of the Carmona government in national newspapers in the following days (González Plessmann, 2002:20). Their commitment to democracy was thus revealed to be circumstantial and not ideological. The willingness of sectors of the opposition to actively conspire to achieve the downfall of a democratically elected government, and to support a clearly authoritarian project in the name of 'democracy', indicates that it is not 'an authentic preoccupation for the strengthening of democracy [which motivates them, but that] they find in the Chávez project a threat or obstacle to their propositions' (González Plessmann, 2002:21).

11 For violent attacks on governing party see, for example, El Nacional 28 February 2002: D/10 for possibility of opposition violence see story on arms cache in home of Pérez Recao see El Nacional 26 April 2002: D/8, identified by Patricia Poleo as a chief co-conspirator (Poleo, 2002); for media smear campaigns see Villegas (2002) on Patricia Poleo's fabrication of videos. 


\section{Barry Cannon}

Clearly then, neither the opposition nor the government can claim entirely accurate accounts. Both sides have elements in their favour: there is evidence of authoritarianism to be found in the Chávez government as the opposition claims, yet there is also evidence to support the governments interpretation of the April events as being a clear case of a coup. Both sides claim to represent democracy, yet both sides have proven themselves to use authoritarianism when it suits them. Rather than being judged for their veracity or lack of it the two accounts represent two visions of Venezuela, as they are indicative of the polarised division of the country into two blocs, a polarisation as we have seen which has deep roots in Venezuelan history, but has long been denied by successive Venezuelan governments, both authoritarian and democratic.

\section{Conclusion: The Fiction of a United Venezuela}

Curiously enough, both documents also reveal some consistencies, in attitudes if not in facts. Deeply engrained in both accounts is a mutual rejection of the legitimacy of the other. The government report, for example, states: 'An elemental error of those involved in the coup was to try to identify themselves as 'civil society' when in effect they were part of the caraqueño society and the middle class' (Asamblea Nacional 2002:24). However, Tablante (2002) insists that Chávez through his actions was responsible for dividing society into 'two sectors', placing the administration at the service of one particular political tendency (Tablante, 2002; Conclusion no.4). Furthermore as seen above, General Vazquez Velasco claimed that the Army acted in the name of 'all Venezuelans'. Both groups disqualify the support of the other sector; for the government, the opposition are 'squalid', few in number and privileged; for the opposition, government supporters are 'chavistas' and 'hordes'. As such, each sector is minoritised and dehumanised; the middle and upper classes overweening oligarchs, the popular classes primitive hordes, harking back to conceptions of civilisation and barbarism. In that vein also Chávez is seen as primitive (Naím, 2001:67), uncouth, unpolished, in effect uncivilised, poor, mixed race, without finesse, 'sin preparación'. Finally, both accounts justified their actions as legal and disqualified the adversary's actions as illegal. And both accounts accused the other of the use of the military to surreptitiously plan violent actions against the people.

There is thus a mutual claim to universality and a negation of the legitimacy of the support of the adversary. Nonetheless, only the government account accepts the class nature of the support behind both groups by identifying it as 'caraqueño' and 'middle class' and their supporters as 'el pueblo'. The opposition, by attributing polarisation to the actions of the President is claiming that by the removal of the President the cause of this polarisation will be also be removed, thus denying its essentially class-based nature.

Why does the opposition refuse to recognise the class divisions of Venezuelan society? First, historically speaking Venezuelan politics lacked a class focus as politics was dominated by the elite/middle-class sectors with little autonomous organisation of the popular classes, a tendency further instituted during the Punto Fijo period. The main parties during that period were multi-class, catch-all parties, and newer class-based 
parties such as MAS and LCR veered more to the centre as they became established. MAS, for example, participated in the Caldera government (1993-1998) responsible for many pro-market reforms with negative impacts on the working and popular classes. The acceptance of a class division of Venezuelan society would therefore in itself be divisive and against the consensual, essentially centrist Venezuelan concepts of liberal democracy, 'the ideological trap of the dominant class' in Carrera Damas' (1980: 86) words.

Second, the opposition itself is heterogeneous and does not share a unitary ideological vision. Many opposition parties are class based, such as LCR, MAS, and Bandera Roja, having developed amongst the working and popular sectors and professing a leftist or centre-left ideology. Other sectors, such as $\mathrm{AD}$ and Copei and Primero Justicia, are more to the centre-right of the political spectrum and come from a multi-class background. Most of these sectors support, explicitly at least, a democratic solution to the crisis, while many other sectors, such as Fedecámaras, on the right, have supported democratic and military solutions, and some sectors on the far right would only support a military solution to the crisis. ${ }^{12}$ Other sectors, such as Arias' Union movement, for example, and many NGOs in 'civil society', urge an exclusively democratic solution to the 'problem' of Chávez. Yet as we have seen most of these sectors were involved in the planning of the coup, or gave it at the very least tacit support. Various documents released by the opposition umbrella organisation, Coordinadora Democrática, for example, propose a democratic solution but do not totally reject the use of a coup as the mechanism to achieve a new government. ${ }^{13}$ The coup failed partially as a result of the abandonment of democracy by the Carmona government thus leading to the withdrawal of important sectors, such as the CTV and many of the political parties. However, these sectors were in principle in support of the coup. In other words, rejection of Chávez transcends ideological differences within the opposition, and the repeated attempts to overthrow him have provided it with a common project.

Furthermore, while some sectors of the opposition may be class-based parties, these have supported Coordinadora Democrática documents which seek market-based solutions to Venezuela's economic problems, within a liberal democratic and a pro-US/ European international context. While the opposition's official discourse concentrates on abstract concepts of freedom and democracy, there is a tacit assumption that the liberal democratic structure will be 'restored' within a market-led economic framework, in effect a class discourse. ${ }^{14}$ The influence of sectors of the left, however, can be found in the repeated prominence given to the 'struggle against poverty' found in these documents. Nevertheless, despite a tacit consensus in the opposition to institute market reforms, there is a lack of agreement as to the exact extent of these reforms, due to the heterogeneous nature of the coalition. Therefore, in these documents, little precise detail is found on how economic reform will be effected. Furthermore, from an opposition point of view, it is dangerous to make policies on market-oriented,

12 http://www.fuerzasolidaria.com/ or http://www.militaresdemocraticos.com/

13 Coordinadora Democrática (2002).

$14 \mathrm{http}: / /$ www.coordinadora-democratica.com/quienessomos.asp for members of Coordinadora Democratica; Coordinadora Democrática (2002). 


\section{Barry Cannon}

neoliberal reform explicit, because of the historical difficulties of these being accepted by the Venezuelan people, particularly the popular classes, as indicated above. Class analysis and acceptance of class divisions would necessitate a discussion on neoliberalism and thus place all opposition parties, but particularly left and centre-left parties, in a difficult situation with regard to their attitudes to such reforms.

Finally, the opposition denial of the class division of Venezuelan society may also be a way to advance the notion of their own popular legitimacy as the true representatives of all the Venezuelan people, thus taking legitimacy away from the Chávez government. Yet as we have seen in Rey's (2002) discussion on the coup above, opposition claims to popular representation are extremely weak. Only Chávez can truly claim to represent all the Venezuelan people as only he has been legitimately elected by the 'sovereign' people of Venezuela in free and fair elections.

Opposition strategies used so far have been radical: intensive media campaigns, a coup, an indefinite general production stoppage, sustained campaigns of popular mobilisation and repeated appeals to the military to intervene (Anonymous, 2002), all elements pointing to an abandonment of dialogue in favour of outright insurrection. Yet, the use of these strategies to force a non-democratic solution to the crisis are indicative of the unwillingness of most opposition sectors to accept the class nature of Venezuelan society and the legitimacy of the Chávez government. It is much more convenient to take Chávez as the cause of division in the country, rather than an expression of it. It could also be said that opposition strategies are equally as polarising and ideologically driven as any of the activities of the Chávez government. Both sides need to accept the legitimacy of the adversary: the government of the extensive and widespread popular support for the opposition, albeit concentrated in the middle- and upper-class sectors, the opposition of the extensive and fervent support for Chávez amongst the popular classes, and the legitimacy of Chávez as a valid interlocutor for those classes, and his government as the legitimate government of Venezuela. It is unlikely that this will happen, however, in the current polarised climate, where politics has become a hegemonic struggle. The consequences, however, of the opposition refusing to acknowledge the class-based nature of the current polarisation of Venezuelan society may simply have the effect of further deepening that polarisation.

\section{References}

Asamblea Nacional/Comisión Parlamentaria Especial para investigar los sucesos de abril de 2002. (2002) Informe de la comisión Parlamentaria Espcial para investigar los sucesos de abril de 2002 (available from http://www.asambleanacional.gov.ve/ns2/varios/ informegrupodelcambio.pdf, downloaded 22/09/03).

Anonymous (2002) Manifiesto de la rebelión constitucional; Desconocemos a Chávez como Presidente; Articulo 350. Documento presentado por varios líderes de la marcha de oposición del jueves 11de julio de 2002, entre ellos Ángela Zago y Julio Borges, a los comandantes de la Base Aérea 'Francisco de Miranda', en el aeropuerto de La Carlota, Caracas, Venezuela (available from http://www.analitica.com/bitblioteca/venezuela/ manifiesto_la_carlota.asp, downloaded 10.12.02).

Buxton, J. (2003) In S. Ellner and D. Hellinger (eds), Venezuelan Politics in the Chávez era: Class Polarization and Conflict pp 113-131. Lynne Rienner: Boulder and London. 
Buxton, J. (2000) Hugo Chávez and populist continuity in Venezuela. Paper for the Political Studies Association-UK 50th Annual Conference, 10-13 April, London (available from http://www.psa.ac.uk/cps/2000/Buxton\%20Julia.pdf, Downloaded 06/08/03).

Carmona Estanga, P. (2002) Decreto del Gobierno Provisional de Pedro Carmona Estanga in Observatorio Social de América Latina Year III, 7: 27-28.

Carrera Damas, G. (1980) Una nación llamada Venezuela. Monte Avila Editores: Caracas.

Carvallo, G. (1994) Próceres, Caudillos y Rebeldes: Crisis del sistema de dominación 1830-1908. Grijalbo/Colleción Tierra Nuestra: Caracas.

Carvallo, G. and López Maya, M. (1989) Crisis en el Sistema Político Venezolano in Cuadernos de CENDES, 10: 47-53.

Civit, J. and España L. P. (1989) Análisis socio-político a partir del estallido del 27 de febrero. Cuadernos de CENDES 10: 35-46.

Coordinadora Democrática (2002) Pacto por la Transición; Por la Unidad y Reconstrucción Nacionales (available from http://www.coordinadora-democratica.com/generados/ docs/pacto_version_12-10.pdf, Downloaded 16/08/03).

Coppedge, M. (2002). 'Venezuela: Popular Sovereignty versus Liberal Democracy'. Helen Kellogg Institute for International Working Paper No.294 [Online]. Available from: http://www.nd.edu/ kellogg/WPS/294.pdf [Accessed, 10 December, 2002].

Coronil, F. (1997) The magical state. The University of Chicago State: Chicago and London.

Coronil, F. and Skurski, J. (1991) Dismembering and remembering the nation: the semantics of political violence in Venezuela. In Comparative Studies in Society and History, Vol. 33: 288-337.

CNE/Consejo Nacional de Elecciones (2003) Resultados ellectorales referendo sindical (available from http://www.cne.gov.ve/estadisticas/e014.pdf, Downloaded 06/08/03).

Datanalisis (1998) Escenarios 1998 Año, II; Número 2.

Datanalisis (2001) Escenarios Julio 2001 Año, IV; Número 3.

ECLAC (2002) Panorama Social de América Latina 2001-2002 Anexo Estadistico (available from http://www.eclac.cl/publicaciones/desarrollosocial/3/LCG2183P/ Anexos_2002.pdf, downloaded 28/08/03).

Ellner, S. (2003) Introductions: the search for explanations. In S. Ellner and D. Hellinger (eds), Venezuelan politics in the Chávez Era, pp. 161-179. Lynne Reinner: Boulder

Ellner, S. and Hellinger, D. (eds) (2003) Venezuelan politics in the Chávez Era: class, polarization and conflict. Lynne Rienner: Boulder and London.

Ewell, J. (1984) Venezuela: a century of change. Stanford University Press: Stanford, CA.

Fleischer, L. R. (2000) Venezuela alert: Chávez Part II. In Center for Strategic and International Studies, 2000, Hemisphere 2000, Vol. VIII, Issue XV, 12 September. Americas section; (available from http://www.csis.org/americas/pubs/hemviii15.html, downloaded 06/07/03).

González Plessmann, A. J. (2002) Venezuela: oposición y estado de derecho. Observatorio Social de América Latina Year III 7: 19-23.

Hellinger, D (2003) Political overview: the breakdown of Puntofijismo and the rise of Chavismo. In S. Ellner and D. Hellinger (eds). pp. 27-54.

Kornblith, M. (1989) Deuda y Democracia en Venezuela: Los sucesos del 27 y 28 de Febrero in Cuadernos del Cendes 10: 17-34.

Lander, E. (1996) The impact of neoliberal adjustment in Venezuela, 1989-1993 Latin American Perspectives 23 (3): 50-73.

Lingenthal, M. (1999) Elecciones en Venezuela. In Constribuciones Año XVI No1 enero-marzo, pp. 219-235.

López Maya, M. (2002) Venezuela: Recuento de una semana fatídica para la democracia in Observatorio Social de América Latina Year III, 7: 23-26.

McCoy, J. and Smith, W. (1995) Democratic disequilibrium in Venezuela. Journal of Interamerican Studies and World Affairs 37 (2): 113-179. 


\section{Barry Cannon}

Myers, D. J. (1996) Venezuela: the stressing of distributive justice. In Wiarda and Kline (eds) Latin American Politics and Development. Westview Press: Boulder.

Naim, M. (2001) La Venezeuela de Chavez. In Polica Exterior XV (82). pp. 51-70.

Njaim, H., Combellas, R., Alvarez, A. E. (1998) Opinión política y democracia en Venezuela. Universidad Central de Venezuela/Facultad de Ciencias Jurídicas y Políticas: Caracas.

OCEI/PNUD (2001) Informe sobre Desarrollo Humano en Venezuela, 2000: Caminos para superar la probreza. CDB publicaciones: Caracas.

Parker, D. (2002) Debilidades en la conducción política del proceso también facilatron el golpe. In Revista de Observatorio Social de América Latina/OSAL Año III No.7/Junio, pp. 5-11.

Poleo, P. (2002) La verdadera historia de un gobierno que duró sólo horas por estar sustentado en los intereses particulares y no en los del colectivo in El Nuevo País 16 April, 2002: 3-4.

Primero Justicia. (2003) Encuesta realizada en conjunto por las firmas Greenberg, Quinlan, Resner Research y Public Opinion Strategies (available from http://www.primerojusticia.org. ve/encuestas/encuestas_archivadas/en_040803.pdf, Downloaded 22/09/03).

PROVEA (2001) Situación de los derechos humanos en Venezuela: Informe Annual Octubre 2000/Septiembre 2001. PROVEA: Caracas.

Rey, J. C. (1991) La democracia venezolana y la crisis del sistema populista de conciliación in Revista de Estudios Politicos (Nueva Epoca) Núm.74, oct-dic, pp. 533-578.

Rey, J. C. (2002) Consideraciones políticas sobre un insólito golpe de Estado, pp. 1-16 (available from http://www.analitica.com/bitblioteca/juan_carlos_rey/insolito_golpe.asp, Downloaded 25 October 2002).

Roberts, K. (2003) Social polarisation and the populist resurgence in Venezuela. In S. Ellner and D. Hellinger, (eds). pp. 55-72.

Tablante, C. (2002) Primer Borrador de la Comisión Política que investiga los sucesos del 11,12,13,y 14 de abril (available from http://www.logiconline.org.ve/primerborrado 1r.htm, Downloaded 10 December 2002).

Vallenilla Lanz, L. (1999) Cesarismo democrático: Estudios sobre las bases sociológicas de la constitución efectiva de Venezuela Caracas: Los Libros de El Nacional/Colección Aries no.14

Various authors (2002) Ante la conspiración mediática en Venezuela (available from http:// www.analitica.com/bitblioteca/varios/conspiracion.asp, Downloaded 10 December, 2002).

Villegas, V. (2002) Mentiras y videos in El Mundo, jueves 13 de junio de 2002 (available from http://www.analitica.com/bitblioteca/vladimir_villegas/mentiras_y_videos.asp, Downloaded 10 December, 2002).

Werz, N. (2001) Chávez en la prensa europea y estadounidense. In Revista Venezolana de Economia y Ciencias Sociales, Vol. 1, no. 2, mayo-agosto, pp. 147-157.

Wright, W. R. (1990) Café con Leche: race, class and national image in Venezuela. University of Texas Press: Austin, TX. 